Original article

\title{
Sunk cost of local elected representatives in situation of fiscal competition: An example of escalating commitment
}

\section{Dépense gâchée des élus locaux en situation de concurrence budgétaire : un exemple de l'escalade dans l'engagement}

\author{
M. Morer ${ }^{\mathrm{a}, *}$, D. Ansel ${ }^{\mathrm{a}}$, F. Michelik ${ }^{\mathrm{b}}$, F. Girandola ${ }^{\mathrm{c}}$ \\ a Laboratoire de psychologie EA 3188, université de Bourgogne-Franche-Comté, 25000 Besançon, France \\ ${ }^{\mathrm{b}}$ FM entreprise, 2, rue du Lac, 25660 Saône, France 3 \\ ${ }^{\mathrm{c}}$ Laboratoire de psychologie sociale, université de Provence, 13621 Aix-en-Provence cedex 1, France
}

\section{A R T I C L E I N F O}

\section{Article history:}

Received 17 November 2015

Accepted 26 November 2017

\section{Keywords:}

Escalating commitment

Fiscal competition

Local elected representatives

Sunk cost

Project completion

\begin{abstract}
A B S T R A C T
Introduction. - Competition between French local communities to build infrastructures to attract enterprises and residents could sometimes result in irrational public spending.

Objectives. - Show the influence of psychological factors and the phenomenon of escalating commitment in particular on this type of economic decision.

Method. - We conducted a survey comprising four scenarios which were sent to 285 local elected representatives and we study the impact of the factors "Amount of sunk costs" and "Level of project completion" on two dependent variables, "the desire to complete the project" and "the judgment regarding the quality of the investment". The scenarios presented a project which involve servicing a site and the construction of a road infrastructure in order to attract an enterprise.

Results. - In conformity with the works of Boehne and Paese, whatever the dependent variable, the level of project completion significantly explains the escalation of commitment. The hypothesis of "sunk costs" is confirmed when the escalation of commitment is measured by the dependent variable "desire to complete the project".

Conclusion. - We have highlighted the effect of sunk costs and level of project completion on the decisions of local elected representatives, enriching the understanding of economic decision factors.
\end{abstract}

(C) 2017 Elsevier Masson SAS. All rights reserved.

\section{R É S U M É}

Introduction. - La concurrence entre collectivités locales françaises en niveaux d'infrastructures pour attirer des entreprises et des habitants peut parfois aboutir à une utilisation irrationnelle de l'argent public.

Objectif. - Montrer l'influence de facteurs psychologiques et de l'escalade d'engagement sur une décision économique.

Méthodes. - Nous avons présenté quatre scenarii à 285 élus locaux et étudié l'impact des facteurs « montant de la dépense gâchée " et " niveau d'achèvement du projet " sur deux variables dépendantes : "le désir d'achever le projet » et " le jugement quant à la qualité de l'investissement ». Les scenarii présentaient un projet de viabilisation d'un terrain d'accueil et de la réalisation d'une infrastructure routière dans le but d'attirer une entreprise.

Résultats. - Conformément aux travaux de Boehne et Paese (2000) le niveau d'achèvement du projet explique significativement l'escalade d'engagement quelle que soit la variable dépendante. L'hypothèse de la " dépense gâchée " est vérifiée lorsque l'escalade d'engagement est mesurée par le " désir d'achever les projet ».

\footnotetext{
* Corresponding author.

E-mail address: myriam.morer@univ-fcomte.fr (M. Morer).
} 
Conclusion. - Nous avons mis en évidence l'effet de la dépense gâchée et du niveau d'achèvement de projet sur les décisions des élus locaux, enrichissant la compréhension des facteurs de décisions économiques. (c) 2017 Elsevier Masson SAS. Tous droits réservés.

In the face of heightened competition between local authorities, elected officials can use public expenditure as a strategic variable to attract businesses and residents. This economic operation is referred to as "fiscal competition" (Wildasin, 1988).

One potential effect of fiscal competition may, for instance, take the form of sunk costs which can only be financed by an increase in taxes or by resorting to debt.

Within the framework of fiscal competition, the impact of sunk costs means that decisions made by local authorities may seem somewhat irrational from an economic perspective. Psychologists refer to this type of economic situation as the "escalation of commitment" (e.g., Girandola, 1999, 2003). Escalation of commitment thus refers to a situation in which an individual or group of individuals invests resources (i.e., time, effort, money) in a goal unlikely to be met (in this case: attract businesses). Moreover, these investments are pursued in spite of negative feedback (Arkes \& Blumer, 1985). Individuals therefore pursue the programs underway to avoid the impression of having wasted money, time or energy at the expense of other, more effective strategies (Joule \& Beauvois, 2014). According to Boehne and Paese (2000), the closer the project inches to completion, the higher the escalation of commitment.

To the best of our knowledge, no research to date has analyzed the fiscal competition. Consequently, this study proposes to shed light on this issue. It draws on a social psychology framework to analyze the economic decisions taken by social actors. The study seeks to evaluate whether or not the escalation of commitment exists among elected authorities through fiscal competition.

\section{The role of sunk costs in the theory of the escalation of commitment}

Drawing on prospect theory as put forward by Kahneman and Tversky (1979), Arkes and Blumer describe sunk costs as an error in judgment. Individuals pursue ongoing action plans to avoid giving the impression of having wasted money, time or energy. In anticipation of losses, most individuals prefer to take risks in the hope of future gains rather than to have the certainty of a moderate loss (Roth, Robbert, \& Strauss, 2015; Thaler, 1985; Tversky \& Kahneman, 1981). The greater the initial investment, the higher the sunken costs. In a 1985 experiment on sunk costs, Arkes and Blumer (1985, Experiment 2) asked research participants to imagine themselves as the CEO of an airline who had to make a decision about an investment opportunity in a project that sought to acquire a new aircraft. In the first condition, participants were informed that the allocated costs would help initiate the project. In the second condition, they learned that $90 \%$ of the project had already been achieved. The results showed that $85 \%$ of the participants in the second group chose to award additional costs to continue the project compared to $16.7 \%$ of the participants in the first condition. Since the studies undertaken by Arkes and Blumer, the theory of commitment (Girandola \& Gueguen, 2014) and, more specifically, the concept of the escalation of commitment have received considerable interest in social psychology (e.g., Ansel, 2005; see Girandola, 1999; Sleesman, Conlon, McNamara, \& Miles, 2012 for a meta-analysis).

Garland and Conlon (1998) further clarified the processes underlying the sunk cost effect. They argued that the effects observed by Arkes and Blumer can be analyzed according to the degree of project completion. Indeed, Arkes and Blumer concluded that the strongest effects of escalation are usually observed when the project is nearer to completion. Thus, more escalation phenomena will be observed when a project is almost complete (90\%) compared to one that has just begun (10\%). Project completion is thus also a factor favoring the escalation of commitment.

In a different study, Boehne and Paese (2000) asked participants the extent to which they were willing to invest in a project. The researchers manipulate three independent variables: the amount of work involved ( 1 million vs. $\$ 9$ million), the rate of completion of the project ( $10 \%$ vs. $90 \%$ ), and the potential sale price ( 1 million vs. $\$ 13$ million). The results showed that the closer the project was to completion (90\%), the stronger was the participants' desire to complete it compared to projects that were far from completion (10\%). In addition participants who were aware that the completed project would fetch a high sales price expressed a stronger desire to complete the project compared to participants in low-priced projects. The results obtained in this particular type of escalation of commitment can be explained by the effect of project completion.

\section{The hypotheses}

Like Boehne and Paese (2000), we argue that the desire to complete a project increases according to what has already been invested in the project and the degree or percentage of project completion. We also believe that the sunk cost effect behavior of local authorities subjected to the pressure of neighboring communities to build infrastructure in order to "win" the localization of a firm on its territory can also be explained by the escalation of commitment. We have thus formulated the following hypotheses:

- hypothesis 1: the commitment of local authorities varies according to the amount of expenses already incurred (100,000 euros or 900,000 euros);

- hypothesis 2: the commitment of local authorities varies according to the degree of completion/percentage of work already achieved ( $10 \%$ or $90 \%)$.

To place local authorities in fiscal competition, our scenarios specify that "the coveted company is negotiating with a neighboring region". Our fictitious scenarios are plausible. Indeed, we can also consider that local authorities are aware of the main financial ratios for each stratum of the population. Thus, according to 2010 management accounts (Observatory on local finance, 2012, p. 134), in a population stratum of fewer than 3500 inhabitants, the ratio produced from direct taxes per capita was 301 euros, the expenditure on equipment per capita was 337 euros, and the per capita debt was 624 euros.

In the context of our research, the budget initially planned, i.e., one million euros, is realistic because for this demographic stratum it implies an average amount of approximately 290 euros as the expenditure on equipment per capita $(1,000,000 / 3500)$. The scenario $(900,000$ euros $/ 10 \%)$ pushes regions to borrow up to 8 million euros, propelling per capita debt to over 2200 euros, excluding interest and the expenditure on equipment per capita which is approximately 2600 euros. The region would thus bear a debt 3.5 times higher than the average debt of its population. 
This scenario would be economically profitable if the expected returns through the servicing of the land was higher than the debt contracted. However, the highest tax per capita in 2010 was 623 euros for cities with 50,000 to 100,000 inhabitants (Observatory on local finance, 2012, p. 134), and these cities are likely to be more developed economically. A small town can hardly expect to achieve a higher ratio.

\section{Methodology}

\subsection{The population}

The data collected was provided by social actors who regularly encounter decisions related to our research question. We conducted a pre-test during the annual conference of the mayors of France and then distributed our questionnaire by uploading it to the official website of the Association of Rural Mayors of France. A total of 285 local officials responded via internet.

\subsection{The investment}

The first scenario describes the following situation:

"You are elected from a small town. You want new companies to set up in your municipality to increase your tax revenues and create jobs for the inhabitants of your municipality. Last year, you were informed about plans for a large company to be set up in your region. You were contacted by the CEO of this company. Then, you undertook to provide the host site of the future company with water, gas and electricity and carried out a road infrastructure. The original project's budget was planned to be 1 million euros in total.

Recently, you received the following information about the progress of the project:

- to date, the project has already cost 100,000 euros;

- the engineers' report shows that $10 \%$ of the project has been carried out;

- the target company is currently negotiating with a neighboring municipality.

You must now decide if you continue this investment or decide to abandon the implementation of this project. The unfinished infrastructure is unusable. If you choose not to reinvest in the project, the remaining amount of 900,000 euros of the initial allocation for the servicing of the land and the construction of the road may be placed. If necessary, your municipality may choose to invest an additional amount to complete this project".

We have written four scenarios taking into account the amounts invested and the percentage of the completed project $(100,000$ euros and $10 \%$ of the project has already been achieved; 900,000 euros and 10\%, 900,000 euros and 90\% and finally 100,000 euros and $90 \%)$.

\subsection{The procedure}

Local elected representatives are invited to answer two questions by Internet using a 10-point Likert scale: "What is your desire to carry out future work?" (on a scale from 0 "very reluctant" to 9 "very eager") and "Do you consider servicing the land and building infrastructure as a good or bad investment?" (on a scale from 0 "very bad investment" to 9 "very good investment"). In accordance with the procedure used by Boehne and Paese (2000), the first scale measures commitment, the second one measures perceived quality of investment. Both of these measures can be considered as an escalation in commitment (Boehne \& Paese, 2000). The elected
Table 1

Measures of escalation of commitment among local authorities.

\begin{tabular}{lll}
\hline Scenario & $\begin{array}{l}\text { Percentage of elected officials } \\
\text { with a score higher than or } \\
\text { equal to 6 } \\
\text { Variable: desire to complete } \\
\text { project }\end{array}$ & $\begin{array}{l}\text { Percentage of elected officials } \\
\text { with a score higher than or } \\
\text { equal to 6 } \\
\text { Variable: quality of investment }\end{array}$ \\
\hline $100 / 10 \%$ & 44.87 & 52.56 \\
$900 / 10 \%$ & 44.78 & 46.27 \\
$900 / 90 \%$ & 78.08 & 65.75 \\
$100 / 90 \%$ & 57.97 & 60.87 \\
\hline
\end{tabular}

representatives were asked to comment on their decisions after responding.

\section{Presentation of the results}

It is considered that there is an escalation of commitment when the elected representative gives a score greater than or equal to the average of the sample (the average for our sample is 5.41 for the desired variable to complete the project). The project is deemed to be of good quality when the elected representative gives a score greater than or equal to the average of the sample (the average for our sample is 5.43 for the quality variable of the investment). Let us then calculate the percentage of local representatives giving a score greater than or equal to 6 , a whole number directly greater than the sample averages (Table 1 ).

There are two possible assumptions to the explanation of escalation of commitment. According to the first assumption (Arkes \& Blumer, 1985), the escalation of commitment will be a function of the sunk cost. Thus, the desire to complete the project will depend on the amount already invested ("sunk cost"). According to the second assumption (Garland \& Conlon, 1998; Boehne \& Paese, 2000), the escalation of commitment is a function of the degree of project completion. Thus, the strongest effects of escalation are usually observed when the project is about to be completed.

We suggest testing these assumptions on our sample of 285 local elected representatives by performing, similar to Boehne \& Paese (2000) $2 \times 2$ Anova according to the amount of the sunk cost (100,000 euros vs. 900,000 euros) and the level of project completion (10\% vs. $90 \%$ ) on our dependent variables "desire to complete the project" and "quality of investment" taken separately.

\subsection{Desire to complete the project}

We achieve main effect of the completion level (F (1, $\left.281)=16.04, p<001 ; \eta^{2}=0.05\right)$. Subjects placed in the condition "high completion level (90\%)" show a greater intention to complete the work $(M=6.16$; $S D=2.96)$ compared to those placed in the condition "low level of completion (10\%)" ( $M=4.70$; $S D=3.28)$.

Similarly, we achieve a main effect of the sunk cost (F ( 1 , $281)=7.52, p=006 ; \eta^{2}=0.02$ ). The elected representatives placed in the strongest sunk cost condition (900,000 euros) express a stronger intention to complete the work harder $(M=5.96$; $\mathrm{SD}=3.12$ ) than those placed in the condition of a smaller sunk cost $(100,000$ euros, $\mathrm{M}=4.91 ; \mathrm{SD}=3.22)$.

\subsection{Investment quality}

We observe a main effect of the "completion level" on the dependent variable "perceived quality of investment" $F$ $(1.281)=9.39, p=002 ; \eta^{2}=0.03$. For example, participants in a "high level of completion (90\%)" consider investment of better quality $(\mathrm{M}=5.95 ; \mathrm{SD}=2.46)$ than those placed in the condition of "low level of completion (10\%)" (M=4.99; $\mathrm{SD}=2.76)$. 
We do not observe any significant influence of the "level of sunk cost" factor on the "investment quality" dependent variable.

\section{Discussion}

The results obtained in this research allow us to argue that the local elected representatives in a situation of fiscal competition are inclined to escalation of commitment, thus confirming previous results (Ansel, 2005) regardless of the two measures of the commitment (desire to complete the project and quality of the investment). At least $45 \%$ of the participants pursue the project or consider it to be of good quality under conditions where a rational economic approach would justify its discontinuation (Kahneman, 2012).

Similar to Boehne and Paese (2000), the assumption of "sunk cost" is not verified as an explanation for the escalation of commitment when measured by the "perceived quality of the investment". However, unlike the results of these two authors, our research shows that this assumption is verified when the escalation of commitment is measured by the "desire to complete the project". We suggest two explanations.

On the one hand, the planned projects are not identical. In our scenarios, regardless of the amount of the sunk costs the benefits for the municipality are uncertain. They depend on the final choice of the company to set up or not on the site under development. The amount of sunk cost becomes a central element that encourages the elected representative to complete the work.

On the other hand, our research differs from that of Boehne and Paese from the perspective of the participants. In our study, local elected representatives are supposed to be experienced in making economic decisions, which is not the case for the first-year students. Failure to escalate and therefore leave an unfinished infrastructure falling apart in the eyes of inhabitants would be a public admission of incompetence. Escalation of commitment can then be understood as a process of self-justification. Brockner (1992) is the first one to highlight the importance of self-justification in explaining the phenomenon of escalation of commitment.

Everything happens as if the local elected representatives tried convincing themselves of the validity of their past choice. This result can be explained by a Goal-Substitution Process (Boehne \& Paese, 2000; Garland \& Colon, 1998). The higher the completion rate of the project, the more money is invested. And in this case, the desire to complete the project for the decision maker increases at the expense of the original economic objective (Humphrey, Moon, Conlon, \& Hofmann, 2004; Jensen, Conlon, Stephen, Humphrey \& Moon, 2011). Some authors consider avoidance techniques for the escalation in commitment (e.g. Wieber, Thürmer, \& Gollwitzer, 2015).

\section{Conclusion}

Our research illustrates the complementarity of economics, social and cognitive psychology to better understand many facets of economic decision-making (e.g. Ariely, 2009; Lassarre \& RolandLévy, 2011; Thaler, 2015; Thaler \& Sunstein, 2008; Tirole, 2016). Decisions that may seem irrational in a classic economic approach of economic models can also be analyzed from sociocognitive benchmarks.

\section{Acknowledgments}

We would like to thank MSHE Nicolas Ledoux and the FrancheComté region for funding this research.

\section{References}

Ansel, D. (2005). Incertitude et escalade d'engagement. Quand coopérer devient risqué. [Uncertainty and escalation of commitment. When cooperation becomes risky]. Les Cahiers Internationaux de Psychologie Sociale - International Journal of Social Psychology, 65, 3-12. http://dx.doi.org/10.3917/cips.065.0003

Ariely, D. (2009). Predictably irrational. Harper Collins/Libri.

Arkes, H., \& Blumer, L. (1985). The psychology of sunk costs. Organizational Behavior and Human Decision Behavior Processes, 35, 124-140. http://dx.doi.org/10.16/0749-5978(85)90049-4

Boehne, D., \& Paese, P. (2000). Deciding whether to complete or to terminate an unfinished project: A strong test of the project completion hypothesis. Organizational Behavior and Human Decision Processes, 81(2), 178-194. http://dx.doi.org/10.1007/s12144-011-9100-7

Brockner, J. (1992). The escalation of commitment to a failing course of action: Towards theoretical progress. The Academy of Management Review, 171, 39-61.

Garland, H., \& Conlon, D. E. (1998). Too close to quit: The role of project completion in maintaining commitment. Journal of Applied Social Psychology, 28, 2025-2048. http://dx.doi.org/10.1111/j.1559-1816.1998.tb01359.x

Girandola, F. (1999). L'escalade de l'engagement: Bilan des recherches [Escalation of commitment: Reviewing the available research]. Les Cahiers Internationaux de Psychologie Sociale - Journal of Applied Social Psychology, 42, 13-34.

Girandola, F. (2003). Psychologie de l'engagement et de la persuasion. [Psychology of commitment and Persuasion]. Presses Universitaires de Franche Comté.

Girandola, F., \& Gueguen, N. (2014). New developments on compliance-gaining procedures. European Review of Applied Psychology, 64, 1-2.

Humphrey, S. E., Moon, H., Conlon, D. E., \& Hofmann, D. E. (2004). Decision-making and behavior fluidity: How focus on completion and emphasis on safety changes over the course of projects. Organizational Behavior and Human Decision Processes, 93, 14-27. http://dx.doi.org/10.1016/j.obhdp.2003.08.003

Jensen, J. M., Conlon, D. E., Stephen, E., Humphrey, S. E., \& Moon, H. (2011). The consequences of completion: How level of completion influences information concealment by decision makers. Journal of Applied Social Psychology, 41, 401-428. http://dx.doi.org/10.1111/j.1559-1816.2010.00719.x

Joule, R. V., \& Beauvois, J. L. (2014). Petit traité de manipulation à l'usage des honnêtes gens. [Short treatise of manipulation for honest people]. Presses Universitaires de Grenoble [Grenoble University Press].

Kahneman, D. (2012). Système 1-Système 2 : Les deux vitesses de la pensée. [System 1 -System 2: Two different thought processes]. Flammarion.

Kahneman, D., \& Tversky, A. (1979). Prospect theory: An analysis of decision under risk. Econometrica, 47(2), 263-291.

Lassarre, D., \& Roland-Lévy, C. (2011). Psychologie sociale appliquée à l'économie. [Social Psychology applied to the economy]. Bruxelles (Brussels): De Boeck (Oxford University Press) (DOI: 10.3917/dbu.lasar.2011.01).

Observatoire des finances locales. (2012). Rapport de l'observatoire des finances locales, les finances des collectivités locales en 2012, juillet. [Observatory on local finance (2012). Report of the Observatory on local finance, finance of local regions in July 2012].

Roth, S., Robbert, T., \& Strauss, L. (2015). On the sunk-cost effect in economic decision-making: A meta-analytic review. Business Research, 8, 99-138. http://dx.doi.org/10.1007/s40685-014-8

Sleesman, D. J., Conlon, D. E., McNamara, G., \& Miles, J. E. (2012). Cleaning up the big muddy: A meta-analysis review of the determinants of escalation of commitment. Academy of Management Journal, 55, 541-562. http://dx.doi.org/10.5465/amj.2010.0696

Thaler, H. R. (1985). Mental accounting and consumer choice. Marketing Science, 4, $199-213$.

Thaler, H. R. (2015). Misbehaving: The making of behavioral economics. W. W. Norton \& Company.

Thaler, H. R., \& Sunstein, R. C. (2008). Nudge. Improving decisions about health, wealth and happiness. Yale: University Press.

Tirole, J. (2016). Économie du bien commun. [Economy for the common good]. Paris: Presses Universitaires de France. [University Press of France].

Tversky, A., \& Kahneman, D. (1981). The framing decision and the psychology of choice. Science, 211, 453-458. http://dx.doi.org/10.1126/science.7455683

Wieber, F., Thürmer, \& Gollwitzer, P. M. (2015). Attenuating the escalation of commitment to a faltering project in the decision-making groups: An implementation intention approach. Social Psychological and Personality Science, 6 587-595. http://dx.doi.org/10.1177/1948550614568158

Wildasin, J. D. (1988). Nash equilibria in model of fiscal competition. Journal of Public Economics, 35, 296-315.

\section{Disclosure of interest}

The authors declare that they have no competing interest. 